\title{
Compositional Characteristics and Antioxidant Activity of Edible Rose Flowers and Their Effect on Phenolic Urinary Excretion
}

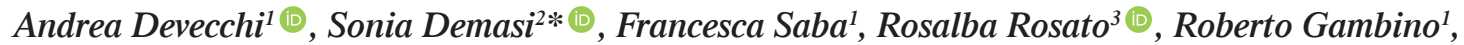 \\ Valentina Ponzo $^{1}$, Antonella De Francesco ${ }^{4}$, Paola Massarenti ${ }^{4}$, Simona Bo ${ }^{1}{ }^{\oplus}$, Valentina Scariot ${ }^{2}$ () \\ ${ }^{1}$ Department of Medical Sciences, University of Turin, Corso Dogliotti 14, 10126, Turin, Italy \\ ${ }^{2}$ Department of Agricultural, Forest and Food Sciences, University of Turin, \\ Largo P. Braccini 2, 10095, Grugliasco (TO), Italy \\ ${ }^{3}$ Department of Psychology, University of Turin, Via Verdi 10, 10124, Turin, Italy \\ ${ }^{4}$ Azienda Ospedaliera Universitaria Città della Salute e della Scienza di Torino, Corso Bramante 88, 10126, Turin, Italy
}

Key words: anthocyanins, bioactive compounds, edible flowers, human study, polyphenols

Petals of edible flowers (EF) are rich in biologically active compounds with many proven benefits for human health. However, studies on the effects of EF in humans after consumption are lacking. This pilot explorative study evaluated the changes in urinary phenolic excretion in healthy volunteers to whom different doses of phenolics from edible roses (Gourmet Roses ${ }^{\mathrm{TM}}$ ) have been added to a meal. Rose petals were picked fresh once a week for three weeks, showing significantly increasing values of total phenolic content, total anthocyanin content, and antioxidant activity (measured as ferric reducing antioxidant power (FRAP) and as $\mathrm{DPPH}^{\cdot}$ and $\mathrm{ABTS}^{\cdot+}$ scavenging activities) from the first to the third week. After the meal, direct associations between urinary phenolics and both the EF phenolic content and the antioxidant activity were found in a multiple regression model. These new insights on EF consumption, to be confirmed by larger trials, suggest that the urinary phenolic excretion of healthy volunteers increases with increasing rose phenolic content.

\section{INTRODUCTION}

Edible flowers (EF) have been used in human nutrition for hundreds of years and are popular in the European, Middle-East, Chinese, and Indian cultures [Lim, 2014a,b; Pires et al., 2019; Scariot et al., 2018], thanks to their taste, beauty, and aromas [Takahashi et al., 2020]. EF are consumed either fresh or minimally processed or in the form of different preparations [Fernandes et al., 2020; Takahashi et al., 2020]. Since the late 1980's, studies revealing the EF chemical composition and properties linked to the presence of several bioactive compounds arose [Demasi et al., 2020; Falla et al., 2020; Fernandes et al., 2020; Grzeszczuk et al., 2016; Rop et al., 2012; Scariot et al., 2018], together with an increased awareness of consumers towards the consumption of natural sources of bioactive compounds [Fernandes et al., 2020; Rop et al., 2012; Takahashi et al., 2020]. Petals of fresh EF are rich in vitamins, minerals, and phenolics, a class of biologically active compounds with many proven benefits [Liu, 2003; Loizzo et al., 2016; Navarro-González et al., 2015; Takahashi et al., 2020]. Adequate intake of phenolics could confer benefits for

\footnotetext{
* Corresponding Author:

E-mail: sonia.demasi@unito.it (S. Demasi)
}

human health, by reducing the risk of cardiovascular, dysmetabolic, and neurodegenerative diseases, and cancer (in particular gastrointestinal neoplasms), by eliciting anti-inflammatory effects, and by favorably modulating the gut microbiota composition [Fraga et al., 2019; Zamora-Ros et al., 2013]. Furthermore, phenolics have been reported to be inversely associated with all-cause mortality and cardiovascular events [Del Bo et al., 2019]. EF have a low-fat content and are rich in water similarly to leafy vegetables [González-Barrio et al., 2018; Rop et al., 2012]. It has also been demonstrated that many EF contain high amounts of phenolics, exceeding those found in fresh fruits and vegetables. For instance, Rosa pendulina petals have a total phenolic content of $\sim 1,700 \mathrm{mg} / 100 \mathrm{~g}$, more than double than blackcurrant $(\sim 800 \mathrm{mg} / 100 \mathrm{~g})$ or blackberry $(\sim 600 \mathrm{mg} / 100 \mathrm{~g})$ fruits [Demasi et al., 2021a; Pérez-Jiménez et al., 2010b]. Looking at single classes of phenolics, petals of Dianthus pavonius contain more than $2,000 \mathrm{mg} / 100 \mathrm{~g}$ of flavonols compared to $\sim 100 \mathrm{mg} / 100 \mathrm{~g}$ in spinach, or Paeonia officinalis contains $\sim 800 \mathrm{mg} / 100 \mathrm{~g}$ of benzoic acid compared to $\sim 120 \mathrm{mg} / 100 \mathrm{~g}$ in raspberry, or finally Taraxacum officinale have $\sim 800 \mathrm{mg} / 100 \mathrm{~g}$ of cinnamic

Submitted: 14 April 2021 Accepted: 28 September 2021 Published on-line: 27 October 2021 
acids compared to the $200 \mathrm{mg} / 100 \mathrm{~g}$ of globe artichoke [Demasi et al., 2021a; Pérez-Jiménez et al., 2010b]. It is therefore evident that it is important to deepen the knowledge on flowers composition in order to understand the role of their phenolics in human metabolism.

The quantity and quality of secondary metabolites and bioactive compounds in petals, similarly to other anatomical parts of plants, may be influenced by several factors. A wide variability in the amount and composition of metabolites in plants have been recorded depending on the genotype [Fiehn, 2002], the stage of development [Piccolella et al., 2018], the environmental conditions [Demasi et al., 2018], the cultivation practices [Caser et al., 2019a,b; Najar et al., 2019], the harvesting time [Pal \& Singh, 2013], and storage [Demasi et al., 2021b].

To date, a few EF species have been investigated and this number is expected to increase [Fernandes et al., 2020; Pires et al., 2019]. Rose (Rosa spp.) is one of the most beloved and known ornamental plants, with a complex genus classification [Martínez et al., 2020; Smulders et al., 2019]. It is among the most frequently consumed EF worldwide [Fernandes et al., 2020], showing a high phenolic content and antioxidant activity according to the genotype [Demasi et al., 2021a; Fernandes et al., 2020; Guimarães et al., 2010; Li et al., 2014; Lu et al., 2016; Zheng et al., 2018]. At present, the contribution of EF to human metabolism in vivo is almost unexplored and data relative to phenolic urinary excretion after EF consumption in humans are lacking. We carried out an exploratory pilot study in a small group of healthy volunteers who were given a week away both a meal and the same meal with the addition of rose petals with different phenolic contents. Then we explored whether the fresh rose characteristics (total phenolic content, total anthocyanin content, and antioxidant activity) were associated with the excretion of phenolics in human urine, after standardization of the meals.

\section{MATERIALS AND METHODS}

\section{Chemicals and apparatus}

Sodium carbonate, sodium acetate, potassium chloride, potassium persulfate, hydrochloric acid, acetic acid, iron(III) chloride hexahydrate, 2,2'-azino-bis(3-ethylbenzothiazoline-6-sulfonic acid) diammonium salt (ABTS), 2,4,6-tripyridyl-s-triazine (TPTZ), 2,2-diphenyl-1-picrylhydrazyl (DPPH radical), Folin-Ciocalteu phenol reagent, and gallic acid were purchased from Sigma Aldrich (St. Louis, MO, USA). Oaxis MAX Cartridges were purchased from Waters (Milford, CT, USA). A Cary 60 UV-Vis spectrophotometer (Agilent, Santa Clara, CA, USA) was used to perform spectrophotometric readings.

\section{Plant material}

Fresh open flowers of Gourmet Roses ${ }^{\mathrm{TM}}$ were provided by the organic nursery RaveraBio ${ }^{\circledR}$ (Rzero Group di Orsini L. \& C., Albenga, SV, Italy) once a week from 1st to 21st June 2019. From each of the three supplies, part of the fresh petals was used for the human experiment, and part was grinded in a mortar using liquid nitrogen, then prepared for the spectrophotometric analysis of total phenolic and total anthocyanin content, and antioxidant activity. One gram of flower powder was extracted with $50 \mathrm{~mL}$ of a water-methanol solution (1:1, $v / v)$ at room temperature with ultrasound-assisted extraction (Sarl Reus, Drap, France) at $23 \mathrm{kHz}$ for $30 \mathrm{~min}$. Three different extractions were performed as replicates for each supply. The solution was filtered with one-layer of filter paper (Whatman No. 1, Maidstone, UK) and preserved at $-20^{\circ} \mathrm{C}$ until the spectrophotometric analyses.

\section{Total phenolic content of roses}

The total phenolic content was analyzed using the Folin-Ciocalteu reagent [Demasi et al., 2021b], by mixing $750 \mu \mathrm{L}$ of the reagent (diluted 1:10) with $150 \mu \mathrm{L}$ of the rose extract and $600 \mu \mathrm{L}$ of $\mathrm{Na}_{2} \mathrm{CO}_{3}(7.5 \%)$. The solution was left in a dark room at room temperature for $30 \mathrm{~min}$. Then, its absorbance was read at $765 \mathrm{~nm}$, and results were expressed as $\mathrm{g}$ of gallic acid equivalents (GAE) per kg of fresh flower ( $\mathrm{gAE} / \mathrm{kg}$ ).

\section{Total anthocyanin content of roses}

The $\mathrm{pH}$-differential method was used for anthocyanin measurement [Demasi et al., 2020]. The rose extract (1 mL) was mixed with $9 \mathrm{~mL}$ of an aqueous buffer solution at $\mathrm{pH} 1$ $(4.026 \mathrm{~g} \mathrm{KCl}+12.45 \mathrm{~mL} \mathrm{HCl} 37 \%$ in a $1 \mathrm{~L}$ water volume $)$ in one flask. In another flask, $1 \mathrm{~mL}$ of the same rose extract was mixed with an aqueous buffer solution at $\mathrm{pH} 4.5(32.82 \mathrm{~g}$ $\mathrm{C}_{2} \mathrm{H}_{3} \mathrm{NaO}_{2}+18 \mathrm{~mL} \mathrm{C}_{2} \mathrm{H}_{4} \mathrm{O}_{2}$ in a $1 \mathrm{~L}$ water volume). The solutions were kept in the dark for $20 \mathrm{~min}$ at room temperature, and their absorbance was read at $515 \mathrm{~nm}$ and $700 \mathrm{~nm}$. Results were expressed as g of cyanidin 3-O-glucoside $(\mathrm{C} 3 \mathrm{G})$ per $\mathrm{kg}$ of fresh flower ( $\mathrm{g} \mathrm{C} 3 \mathrm{G} / \mathrm{kg}$ ).

\section{Antioxidant activity of roses}

The antioxidant activity of roses was analyzed using different assays: the ferric reducing antioxidant power (FRAP), DPPH, and ABTS [Demasi et al., 2021b]. The FRAP assay was performed by mixing $30 \mu \mathrm{L}$ of the rose extract with $90 \mu \mathrm{L}$ of deionized water and $900 \mu \mathrm{L}$ of the FRAP reagent. The solution was kept for $30 \mathrm{~min}$ at $37^{\circ} \mathrm{C}$, and then its absorbance was measured at $595 \mathrm{~nm}$, and results were expressed as millimoles of ferrous iron $\left(\mathrm{Fe}^{2+}\right)$ equivalents per $\mathrm{kg}\left(\mathrm{mmol} \mathrm{Fe}^{2+} / \mathrm{kg}\right)$. The DPPH assay was performed with the following procedure: a DPPH ${ }^{\cdot}$ solution was obtained by the reaction of $2 \mathrm{mg}$ of $\mathrm{DPPH}^{\cdot}$ with $50 \mathrm{~mL}$ of $\mathrm{MeOH}$, up to the absorbance of 1.000 at $515 \mathrm{~nm}$. Then, $3 \mathrm{~mL}$ of the $\mathrm{DPPH}^{\cdot}$ solution was mixed with $40 \mu \mathrm{L}$ of the rose extract. The mixture was left in the dark at room temperature for $30 \mathrm{~min}$, and then its absorbance was measured at $515 \mathrm{~nm}$. The ABTS assay was performed with the following procedure: the ABTS radical cation solution was obtained by the reaction of $7.0 \mathrm{mM}$ ABTS with $2.45 \mathrm{mM} \mathrm{K}_{2} \mathrm{~S}_{2} \mathrm{O}_{8}$, incubated for $12-16 \mathrm{~h}$ in the dark at room temperature and diluted with distilled water until the absorbance of 0.70 had been achieved at $734 \mathrm{~nm}$. Then, $2 \mathrm{~mL}$ of the diluted $\mathrm{ABTS}^{\bullet+}$ solution was mixed with $30 \mu \mathrm{L}$ of the rose extract. The mixture was left in the dark at room temperature for $10 \mathrm{~min}$, and then its absorbance was measured at $734 \mathrm{~nm}$. In both DPPH and ABTS methods the results were expressed as mmol of Trolox equivalents (TE) per kilogram (mmol TE/kg).

The water-methanol $(1: 1, v / v)$ extraction solution was used as control in each analysis instead of the rose extract. 


\section{The human experiment}

Twenty healthy volunteers were enrolled for the experiment. Inclusion criteria were age 20-70 years, and a body mass index (BMI) 20-29 $\mathrm{kg} / \mathrm{m}^{2}$. Exclusion criteria were: treatment with any drugs and/or supplements, subjects in any dietary regimen, pregnant and/or lactating women, the presence of any known disease, active smoking, inability to express informed consent to the study, and known flower allergy. The study was conducted following a randomized cross-over design [Kuntz et al., 2015] and all participants received the same meal without $(\mathrm{M}$; meal without $\mathrm{EF})$ or with (EFM; meal + EF) the addition of $17 \mathrm{~g}$ of rose petals after 1 week of wash out. Participants were randomized to receive as a first meal either the meal without EF (M) or the same meal with the addition of EF (EFM). Meals were prepared by the same researcher in the same place; each meal consisted of 2 courses, and their composition is reported in Table 1 .

In a random order, 7, 8, and 5 participants received the EFM supplied respectively in the first, second, and third week. Randomization sequence was computer-generated by a statistician. Participants were to consume either the $\mathrm{M}$ or the EFM in 60-min under researchers' supervision at 1:00 pm at the kitchen of the School of Dietetics (University of Turin). Volunteers had to eat both the two courses each of the two days of the experiment. During each meal, only water was allowed. The same dietary recommendations for the 24-h before each test and the 24-h after each test were given to all participants. The energy content was calculated according to the participant's energy need (range 1500-1900 kcal); the dietary composition was $20 \mathrm{~g} / 100 \mathrm{~g}$ proteins, $30 \mathrm{~g} / 100 \mathrm{~g}$ lipids, $50 \mathrm{~g} / 100 \mathrm{~g}$ carbohydrates. Fiber intake was restricted to $17 \mathrm{~g} /$ day, by reducing phenolic-rich foods (no more than $250 \mathrm{~g}$ fruit/day -only peeled apple and banana allowed-, no more than $200 \mathrm{~g}$ vegetables/day -only lettuce and zucchini allowed-, no wine, no tea, no coffee, no cocoa) in order to avoid interference from dietary polyphenols. The dietary phenolic intake was calculated according to the published database [Neveu et al., 2010;
Rothwell et al., 2013]. Each participant completed both a 1-day food record to collect data relative to food consumption 24-h before each experiment and a validated food-frequency questionnaire to obtain data relative to usual dietary habits. Diet adherence was verified both by the 1-day food recall and by telephone interview with each participant the day before the experiment. Urine collection began from 4:00 pm of the day of the test until 4:00 pm of the day after the test. Each volunteer was asked to urinate before the meal and then to wait until 4:00 pm before the next voiding. All procedures were in agreement with the principles of the Helsinki Declaration; the study protocol, the questionnaires used, the informed consent, the information for the participant and the curriculum vitae of the researchers were submitted to the attention of the Local Bioethics Committee of the University of Turin on 25 March 2019. The study protocol was approved by the Local Bioethics Committee of the University of Turin (No.176859, Turin, Italy) on 2 May 2019. Informed consent was obtained from all individual participants included in the study.

\section{Total phenolic content of urine}

Urine samples were collected into sterilized $1.5 \mathrm{~L}$ bottles, acidified with $\mathrm{HCl}$ to preserve the phenolic compounds in line with literature [Roura et al., 2006], and processed the following morning to avoid formation of artefacts and loss of phenolic content. The total phenolic content excreted in urine after consumption of the test meals was determined with Folin-Ciocalteu assay after purifying the samples by solid-phase extraction according to literature [Medina-Remón et al., 2009], with the difference that the solid-phase extraction was carried out through Oaxis MAX Cartridge Waters containing the same stationary phase as micro titer 96-well plate cartridges. Briefly, $1 \mathrm{~mL}$ of acidified urine was applied to an activated Waters Oasis MAX cartridge. The cartridge was rinsed with $4 \mathrm{~mL}$ of sodium acetate $50 \mathrm{mM} \mathrm{pH} \mathrm{7/5 \%} \mathrm{metha-}$ nol. The phenolics were eluted with $1.8 \mathrm{~mL}$ of $2 \%(\mathrm{v} / \mathrm{v})$ formic acid in methanol. Then, $30 \mu \mathrm{L}$ of the eluted fractions were mixed with $340 \mu \mathrm{L}$ of deionized water adding $25 \mu \mathrm{L}$

TABLE 1. Composition of the meal $(\mathrm{M})$ received by the participants. The meal with edible flowers (EFM) was the same with the addition of $17 \mathrm{~g}$ of rose petals.

\begin{tabular}{|c|c|c|c|c|c|c|c|}
\hline Meal & Ingredient & Quantity (g) & Proteins (g) & Lipids (g) & Carbohydrates (g) & Fiber (g) & Total kcal \\
\hline \multirow{5}{*}{ Vegetable noodles } & Noodles & 80 & 7.3 & 1.7 & 39.5 & 1.81 & \\
\hline & Courgettes & 60 & 0.81 & 0 & 0.87 & 0.87 & \\
\hline & Carrots & 50 & 0.55 & 0 & 3.8 & 1.55 & \\
\hline & Ricotta & 40 & 3.5 & 4.37 & 1.4 & 0 & \\
\hline & Olive oil & 10 & 0 & 10 & 0 & 0 & \\
\hline \multirow{4}{*}{$\begin{array}{l}\text { Baked fish fillet } \\
\text { with yogurt sauce }\end{array}$} & Cod & 100 & 17 & 0.3 & 0 & 0 & \\
\hline & Natural yogurt & 50 & 1.9 & 1.95 & 2.15 & 0 & \\
\hline & Cucumbers & 15 & 0.1 & 0 & 0.3 & 0.11 & \\
\hline & Olive oil & 5 & 0 & 5 & 0 & 0 & \\
\hline Intake (per capita) & & & 30 & 23 & 48 & 4.34 & 520 \\
\hline
\end{tabular}


of the Folin-Ciocalteu reagent and $60 \mu \mathrm{L}$ of sodium carbonate $(200 \mathrm{~g} / \mathrm{L})$. The mixture was incubated for $1 \mathrm{~h}$ at room temperature in the dark. Later, $145 \mu \mathrm{L}$ of deionized water was added. Absorbance was measured at $765 \mathrm{~nm}$. Results were expressed as mg gallic acid equivalent per liter $(\mathrm{mg} / \mathrm{L})$ and per day (mg/day).

\section{Statistical analyses}

Flowers' variables and human data were reported as means \pm standard deviations. For each rose's phytochemical parameter, differences between the three samples were analyzed by non-parametric analysis of variance using Kruskal-Wallis test, with stepwise comparison, and by Spearman's correlation analyses. Between-group differences in urinary phenolic excretion were analyzed by Kruskal-Wallis test. Analyses were performed using SPSS 24.0 Inc. software (SPSS Inc., Chicago, IL, USA). Crude and adjusted linear regression models were used to examine the urinary phenolic excretion (dependent variable) in relation to each compositional characteristics and antioxidant activity of edible rose flowers: (a) the flower total phenolic, (b) the total anthocyanin contents, and (c) the antioxidant activity. A multiple regression model adjusted for age, sex, BMI, and dietary phenolic intake was estimated for each phytochemical characteristic (a, b, c). These analyses were done with Statistica software (ver. 7.0; StatSoft Inc., Tulsa, OK, USA).

\section{RESULTS AND DISCUSSION}

\section{Bioactive compounds in rose petals}

The content of phenolics and anthocyanins in rose petals and their antioxidant activity are reported in Table 2. The total phenolic content $(6.53,8.01$, and $11.71 \mathrm{~g} \mathrm{GAE} / \mathrm{kg})$ and the FRAP (298.23, 407.41, $564.77 \mathrm{mmol} \mathrm{Fe}{ }^{2+} / \mathrm{kg}$ ) significantly differed in each sample, increasing from the first to the third week of EF supply. Similarly, anthocyanin content (0.86-1.36 g C3G/kg), DPPH• (26.67-45.58 mmol TE/kg), and $\mathrm{ABTS}^{\bullet+}$ (9.49-14.12 mmol TE/kg) scavenging activities were higher in the third sample. All the evaluated parameters of EF were positively highly correlated with each other ( $p$ values were always lower than 0.01), as reported in Table 3.

Rosa is an extremely wide and complex genus of plant and comprises more than 150 species and 30,000 cultivars [Smulders et al., 2019]. Some of them have already been studied as edible flowers and source of bioactive compounds (e.g. Rosa $\times$ hybrida, Rosa $\times$ odorata, Rosa centifolia, Rosa chinensis, Rosa gallica, Rosa micrantha, Rosa damascena, Rosa bourboniana, Rosa brunonii, and Rosa rugosa), and results showed a wide variability according to the species [Chen et al., 2018; Guimarães et al., 2010; Kumar et al., 2009; Li et al., 2014; Lu et al., 2016; Mohsen et al., 2020; Rop et al., 2012; Zhang et al., 2014; Zheng et al., 2018]. Different analytical assays

TABLE 2. Total phenolic and total anthocyanin contents, and antioxidant activity measured as ferric reducing antioxidant power (FRAP) and as DPPH $^{\bullet}$ and ABTS $^{\bullet+}$ scavenging activities of edible roses (Gourmet Roses ${ }^{\mathrm{TM}}$ ) supplied in the first, second, and third week of June 2019.

\begin{tabular}{l|c|c|c|c|c}
\hline Rose supply & $\begin{array}{c}\text { Total polyphenol } \\
\text { content } \\
(\mathrm{g} \mathrm{GAE} / \mathrm{kg})\end{array}$ & $\begin{array}{c}\text { Total anthocyanin } \\
\text { content } \\
(\mathrm{g} \mathrm{C} 3 \mathrm{G} / \mathrm{kg})\end{array}$ & $\begin{array}{c}\mathrm{FRAP}^{2} \\
\left(\mathrm{mmol} \mathrm{Fe}^{2+} / \mathrm{kg}\right)\end{array}$ & $\begin{array}{c}\text { DPPH}{ }^{\bullet} \\
\text { scavenging activity } \\
(\mathrm{mmol} \mathrm{TE} / \mathrm{kg})\end{array}$ & $\begin{array}{c}\text { ABTS }^{\bullet+} \\
\text { scavenging activity } \\
(\mathrm{mmol} \mathrm{TE} / \mathrm{kg})\end{array}$ \\
\hline $\mathrm{n} .1$ & $6.53 \pm 0.70^{\mathrm{c}}$ & $0.86 \pm 0.09^{\mathrm{b}}$ & $298.23 \pm 35.75^{\mathrm{c}}$ & $26.67 \pm 1.47^{\mathrm{b}}$ & $9.49 \pm 1.92^{\mathrm{b}}$ \\
$\mathrm{n} .2$ & $8.01 \pm 0.19^{\mathrm{b}}$ & $0.97 \pm 0.02^{\mathrm{b}}$ & $407.41 \pm 16.53^{\mathrm{b}}$ & $28.36 \pm 2.62^{\mathrm{b}}$ & $9.96 \pm 0.49^{\mathrm{b}}$ \\
$\mathrm{n} .3$ & $11.71 \pm 0.40^{\mathrm{a}}$ & $1.36 \pm 0.08^{\mathrm{a}}$ & $564.77 \pm 6.45^{\mathrm{a}}$ & $45.58 \pm 0.82^{\mathrm{a}}$ & $14.12 \pm 0.17^{\mathrm{a}}$ \\
$p$ & 0.00003 & 0.0004 & 0.00002 & 0.00002 & 0.005 \\
\hline
\end{tabular}

Results are expressed as mean of three replicates \pm standard deviation; different letters indicate significant differences in a column according to Kruskal-Wallis stepwise comparisons ( $p \leq 0.05)$. GAE - gallic acid equivalent; $\mathrm{C} 3 \mathrm{G}$ - cyanidin 3 - $O$-glucoside; TE - Trolox equivalent.

TABLE 3. Spearman's correlation coefficients between total phenolic content, total anthocyanin content, and antioxidant activity measured as ferric reducing antioxidant power (FRAP) and as $\mathrm{DPPH}^{\bullet}$ and $\mathrm{ABTS}^{\bullet+}$ scavenging activities of edible roses (Gourmet Roses ${ }^{\mathrm{TM}}$ ).

\begin{tabular}{|c|c|c|c|c|c|}
\hline & & FRAP & DPPH ${ }^{\circ}$ scavenging activity & $\mathrm{ABTS}^{\cdot+}$ scavenging activity & Total anthocyanin content \\
\hline \multirow{2}{*}{ Total phenolic content } & $\begin{array}{c}\text { Correlation } \\
\text { coefficient }\end{array}$ & 0.983 & 0.850 & 0.803 & 0.833 \\
\hline & $p$ & 0.000 & 0.004 & 0.009 & 0.005 \\
\hline \multirow{2}{*}{ FRAP } & $\begin{array}{c}\text { Correlation } \\
\text { coefficient }\end{array}$ & & 0.883 & 0.820 & 0.850 \\
\hline & $p$ & & 0.002 & 0.007 & 0.004 \\
\hline \multirow{2}{*}{ DPPH ${ }^{\bullet}$ scavenging activity } & $\begin{array}{c}\text { Correlation } \\
\text { coefficient }\end{array}$ & & & 0.887 & 0.800 \\
\hline & $p$ & & & 0.001 & 0.010 \\
\hline \multirow{2}{*}{$\mathrm{ABTS}^{\cdot+}$ scavenging activity } & $\begin{array}{c}\text { Correlation } \\
\text { coefficient }\end{array}$ & & & & 0.937 \\
\hline & $p$ & & & & 0.000 \\
\hline
\end{tabular}


(e.g. FRAP, DPPH, and ABTS, or total phenolic content) are necessary to evaluate the antioxidant activity of matrices. However, different extraction and analytical methods, and sample preparation could make the comparison among different studies difficult [Santos-Buelga et al., 2012]. The range of total phenolic content has been reported to vary from 5.00 to $24.00 \mathrm{~g}$ GAE $/ \mathrm{kg}$ in $R . \times$ hybrida and $R . \times$ odorata [Li et al., 2014; Rop et al., 2012], while other authors [Chen et al., 2018] found $74 \mathrm{~g}$ GAE/kg in pink $R$. rugosa (on dry weight). Twelve rose cultivars are reported to have a total anthocyanin content ranging from 0 to $2.50 \mathrm{~g} \mathrm{C} 3 \mathrm{G} / \mathrm{kg}$ [Friedman et al., 2010]. In four rose species [Zheng et al., 2018], ranges of 360-3620 mmol Fe ${ }^{2+} / \mathrm{kg}$ were recorded with FRAP, and 239-1037 mmol TE/kg with ABTS assay. ABTS ${ }^{\bullet+}$ scavenging activities of 2-36 mmol TE/kg and $653 \mathrm{mmol} \mathrm{TE} / \mathrm{kg}$ were reported in fresh flowers of 12 rose cultivars [Friedman et al., 2010] and in dry flowers of $R$. rugosa [Zhang et al., 2014], respectively. In turn, $101 \mathrm{mmol}$ TE/kg (by ABTS assay) and $451 \mathrm{mmol} \mathrm{Fe}^{2+} / \mathrm{kg}$ (by FRAP) were recorded in $R$. $\times$ hybrida petals [Li et al., 2014]. Our results on Gourmet Roses ${ }^{\mathrm{TM}}$ petals are consistent with the above-mentioned ranges, except for the DPPH assay, which detected lower values than those reported in literature $(243-520 \mathrm{mmol}$ TE/kg) [Chen et al., 2018; Zheng et al., 2018].

The petals of roses harvested at one-week distance during the month of July showed an increasing content over time in bioactive compounds, namely total phenolics, and anthocyanins. Consequently, an increased antioxidant activity was found. These parameters were positively correlated, confirming previous results on edible plants and wildflowers [Demasi et al., 2021a; Li et al., 2014]. The secondary metabolite content in roses varies among species and may be triggered by various stimuli, which commonly occur because of seasonal variations, or biotic and abiotic stresses. Similarly, also the phenological stage and senescence of the plant could have determined an increased production of antioxidants, such as phenolic compounds, as a defense system that can lead to increments both in the phenolic content and the biological activity over time [Piccolella et al., 2018].

\section{Urinary phenolic content}

Twenty volunteers participated in the study (12 males, 8 females); their mean age and BMI were 41.2 \pm 10.8 years and $22.6 \pm 3.2 \mathrm{~kg} / \mathrm{m}^{2}$, respectively. Their usual mean phenolic dietary intake was $931.3 \pm 219.1 \mathrm{mg} /$ day. The 24 -h before each experiment, the mean phenolic dietary intake was lower $(784.5 \pm 230.4 \mathrm{mg} /$ day) in line with the given dietary recommendations for those days. Diet adherence was evaluated by 1-day food record and telephone interview the day before each experiment and resulted to be adequate. Out of them, 2 volunteers ( 1 male and 1 female, both receiving the third EF sample) did not perform a correct 24-h urine collection. Therefore, the urine samples of 18 subjects were analyzed. No adverse effects related to the EF assumption were reported by participants.

The differences in urinary phenolic excretion (expressed as $\mathrm{mg} / \mathrm{L}$ or $\mathrm{mg} /$ day) between the participant consuming EFM and $\mathrm{M}$ were $-1.8 \pm 11.4,7.0 \pm 14.6,59.1 \pm 94.6 \mathrm{mg} / \mathrm{L}$ $(p=0.15$ according to Kruskal-Wallis) and $-4.5 \pm 20.2$, $6.8 \pm 10.9,72.7 \pm 124.1 \mathrm{mg} /$ day $(p=0.15)$, respectively from the first, second, and third supply of roses. The associations between the urinary human phenolic excretion (dependent variable) and the EF characteristics, namely total phenolic and total anthocyanin content, and antioxidant activity are shown in Table 4. Direct significant associations were found with all the EF characteristics in both crude and adjusted models, in which four variables potentially impacting the intake or excretion of phenolics (age, gender, body mass index, and dietary phenolic intake) were considered. It is reassuring that the associations remain statistically significant in the adjusted model, despite the small size of the sample (20 participants). This might suggest a potential influence of the rose characteristics on the human absorption of the rose phenolic content.

TABLE 4. Parameters of a regression model for relationships between differences in 24-h urinary phenolic excretion of participants consuming meal with and without edible flower, and the roses (Gourmet Roses ${ }^{\mathrm{TM}}$ ) characteristics.

\begin{tabular}{|c|c|c|c|c|c|c|c|}
\hline Characteristics & Model & $\beta_{1}$ & $\mathrm{SE}_{1}$ & $p_{1}$ & $\beta_{2}$ & $\mathrm{SE}_{2}$ & $p_{2}$ \\
\hline \multirow{2}{*}{$\begin{array}{l}\text { Total phenolic content } \\
\text { (g GAE/kg) }\end{array}$} & Crude & 0.11 & 0.048 & 0.031 & 0.15 & 0.063 & 0.032 \\
\hline & Adjusted $^{\mathrm{a}}$ & 0.16 & 0.063 & 0.030 & 0.19 & 0.084 & 0.044 \\
\hline \multirow{2}{*}{$\begin{array}{l}\text { Total anthocyanin content } \\
\text { (g C } 3 \mathrm{G} / \mathrm{kg})\end{array}$} & Crude & 1.21 & 0.50 & 0.027 & 1.58 & 0.65 & 0.027 \\
\hline & Adjusted & 1.65 & 0.65 & 0.026 & 2.03 & 0.86 & 0.035 \\
\hline \multirow{2}{*}{$\begin{array}{l}\text { Ferric reducing } \\
\text { antioxidant power } \\
\left(\mathrm{mmol} \mathrm{Fe}^{2+} / \mathrm{kg}\right)\end{array}$} & Crude & 0.20 & 0.09 & 0.046 & 0.26 & 0.12 & 0.049 \\
\hline & Adjusted & 0.28 & 0.12 & 0.047 & 0.32 & 0.17 & 0.07 \\
\hline \multirow{2}{*}{$\begin{array}{l}\text { DPPH• scavenging activity } \\
(\mathrm{mmol} \mathrm{TE} / \mathrm{kg})\end{array}$} & Crude & 3.10 & 1.24 & 0.024 & 4.09 & 1.62 & 0.022 \\
\hline & Adjusted & 4.27 & 1.64 & 0.023 & 5.40 & 2.12 & 0.026 \\
\hline \multirow{2}{*}{$\begin{array}{l}\mathrm{ABTS}^{\bullet}+\text { scavenging activity } \\
(\mathrm{mmol} \mathrm{TE} / \mathrm{kg})\end{array}$} & Crude & 12.85 & 5.15 & 0.024 & 16.90 & 6.70 & 0.023 \\
\hline & Adjusted & 17.67 & 6.78 & 0.023 & 22.24 & 8.79 & 0.026 \\
\hline
\end{tabular}

a adjusted - multiple regression model adjusted for age, gender, body mass index, and dietary polyphenol intake. $\beta_{1}, \mathrm{ES}_{1}, p_{1}-$ parameters for urinary phenolic excretion expressed in $\mathrm{mg} / \mathrm{L} ; \beta_{2}, \mathrm{ES}_{2}, p_{2}$ - parameters for urinary phenolic excretion expressed in $\mathrm{mg} / \mathrm{day}$. $\beta$ - regression coefficient; SE - standard error; GAE - gallic acid equivalent; $\mathrm{C} 3 \mathrm{G}$ - cyanidin 3-O-glucoside; TE - Trolox equivalent. 
Polyphenols bioavailability varies widely among different classes of phenolics and they can be absorbed and metabolized differently according to their chemical structure [Teng \& Chen, 2019]. Briefly, part of them are absorbed by the small intestine, while part are metabolized by microbiota. The metabolites reach the liver to be absorbed by tissues and cells or the kidneys, to be ultimately excreted through urine. Phenolic intake from food has been therefore associated with human total urinary phenolic excretion [Nielsen et al., 2002; Mennen et al., 2006; Pérez-Jiménez et al., 2010a; Roura et al., 2006; Spencer et al., 2008; Zamora-Ros et al., 2011]. A systematic review has suggested that urinary phenolics might be considered as an indicator of phenolic intake [Pérez-Jiménez et al., 2010a]. An increased consumption of phenolic compounds with diet has been reported to reduce cardiovascular risk factors [Guo et al., 2016; Medina-Remón et al., 2017], the incidence of type 2 diabetes mellitus [Wedick et al., 2012], cardiovascular events, and all-cause mortality [Agudo et al., 2007; Alonso et al., 2004; Covas et al., 2001; Grassi et al., 2005; Manach et al., 2005; Tresserra-Rimbau et al., 2014a,b], and to decrease blood concentrations of inflammatory biomarkers [Medina-Remón et al., 2017]. The beneficial effects of dietary polyphenols may also be due to a bi-directional relationship with the gut microbiota: polyphenols can favorably affect the gut microbiota composition, and the gut microflora could metabolize polyphenols into beneficial bioactive compounds, such as chlorogenic acid and the derived compounds [Fraga et al., 2019; Liu et al., 2020a; Ozdal et al., 2016; Tomas-Barberan et al., 2014].

At present, only in vitro and animal studies evaluated the effects of EF phenolics. The anti-inflammatory property of extract of $R$. canina, tested on the carrageenin-induced rat paw edema assay, was demonstrated by the inhibition of carrageenin-induced edema, similarly to the effect of indomethacin [Lattanzio et al., 2011]. Flower compounds have been reported both to induce cell apoptosis via the p53 signalling and p38 MAPK/FasL (mitogen-activated protein kinase-FAS ligand) cascade pathways [Lin et al., 2005; Lo et al., 2007] and to ameliorate the ROS-mediated mitochondrial dysfunction pathway [Hou et al., 2005; Lin et al., 2005; Lo et al., 2007]. Hibiscus acid from Hibiscus sabdariffa (roselle) and (+)-epimagnolin A and (+)-magnolin from Magnolia denudata induced weight loss in animals and in in vitro experiments, by acting on fat metabolism-related enzymes, down-regulating adipocyte differentiation via the modulation of the PI3K (phosphoinositide 3-kinase) and MAP-kinase pathways and inhibiting $\alpha$-amylase activity and sugar/starch absorption [Hansawasdi et al., 2001; Kim et al., 2007; Kong et al., 2011; Preuss et al., 2007]. Similarly, the methanol extract of Nymphaeaceae inhibited the lipid storage in adipocytes by promoting lipolysis [Hansawasdi et al., 2001; Lee et al., 2010; Kong et al., 2011; Velusami et al., 2013]. Rosa spp. are very rich in quercetin, which has been shown to inhibit both $\alpha$-glucosidase and $\alpha$-amylase, thus reducing the intestinal absorption of glucose [Lu et al., 2016; Oboh et al., 2015]. However, different EF showed great variability in their phenolic composition and bio-accessibility through an in vitro digestion model coupled to a simulated intestinal barrier [de Morais et al., 2020]. Thus, in vivo and human studies are needed to define the potential role of EF on human health.
This is the first human study analyzing the relationship between the dietary content of phenolics from EF and the urinary phenolic excretion in healthy volunteers. According to the multiple regression analysis, we found a direct relationship between the increasing rose phenolic content and the phenolic excretion, meaning that phenolics have been absorbed and metabolized by the body [Pérez-Jiménez et al., 2010a].

\section{CONCLUSIONS}

The preliminary data of this pilot explorative study suggest the importance of carrying out further human trials to characterize the absorption of the phenolics contained in the EF and their impact on the human oxidative status. Indeed, edible roses were confirmed as a rich source of bioactive compounds (total phenolics and total anthocyanins) with high antioxidant activity, and the increasing values of these parameters in flowers corresponded to an increase of the urinary phenolic excretion in healthy volunteers. Interestingly, the amount of EF used in the recipes $(17 \mathrm{~g})$ provided an amount of phenolics (111-199 mg GAE) proper to fill the gap between the dietary recommendations during the trial (784 $\mathrm{mg}$ /day) and the usual mean dietary intake of the participants $(931 \mathrm{mg} /$ day), suggesting that no other supplemented phenolics are required to meet their needs. Though, we cannot exclude the possibility that an absorption plateau could be reached at a specific threshold of phenolic intake by EF supplementation. In order to reduce the risk of bias, the conditions were standardized as much as possible before and during the human experiment and the participants reported an adequate compliance to the given dietary recommendations. Even though for the purposes of a pilot study any sample size from 12 upwards has been considered adequate [Julious, 2005], a larger sample of participants will be needed for future studies to specifically test a dose-response relationship [Shader, 2015]. Moreover, the evaluation, besides urine, also of blood markers of oxidative stress, inflammation, kidney and liver function would be of interest to define the efficiency of phenolics absorption and the potential benefits and safety of adding specific EF in daily diet.

\section{ACKNOWLEDGEMENTS}

Authors thank RZero Group s.r.l. for providing rose flowers, and Mina Novello for suggesting the recipes.

\section{RESEARCH FUNDING}

This research was partially funded by the program Interreg V-A Francia Italia Alcotra, project n. 1139 "ANTEA - Attività innovative per lo sviluppo della filiera transfrontaliera del fiore edule".

\section{CONFLICT OF INTEREST}

The authors declare that this study received component from RZero Group s.r.l. The provider was not involved in the study design, collection, analysis, interpretation of data, the writing of this article or the decision to submit it for publication. 


\section{ORCID IDs}

S. Bo https://orcid.org/0000-0001-6862-8628

S. Demasi https://orcid.org/0000-0001-6223-5436

A. Devecchi https://orcid.org/0000-0003-2508-1110

R. Rosato https://orcid.org/0000-0002-4921-374X

V. Scariot https://orcid.org/0000-0003-0195-1361

\section{REFERENCES}

1. Agudo, A., Cabrera, L., Amiano, P., Ardanaz, E., Barricarte, A., Berenguer, T., Chirlaque, M.D., Dorronsoro, M., Jakszyn, P., Larrañaga, N., Martínez, C., Navarro, C., Quirós, J.R., Sánchez, M.J., Tormo, M.J., González, C.A. (2007). Fruit and vegetable intakes, dietary antioxidant nutrients, and total mortality in Spanish adults: findings from the Spanish cohort of the European Prospective Investigation into Cancer and Nutrition (EPIC-Spain). The American Journal of Clinical Nutrition, 85(6), 1634-1642.

https://doi.org/10.1093/ajcn/85.6.1634

2. Alonso, A., de la Fuente, C., Martín-Arnau, A.M., de Irala, J., Alfredo Martínez, J., Martínez-González, M.Á. (2004). Fruit and vegetable consumption is inversely associated with blood pressure in a Mediterranean population with a high vegetable-fat intake: the Seguimiento Universidad de Navarra (SUN) Study. British Journal of Nutrition, 92(2), 311-319. https://doi.org/10.1079/BJN20041196

3. Caser, M., Chitarra, W., D’Angiolillo, F., Perrone, I., Demasi, S., Lovisolo, C., Pistelli, L., Pistelli, L., Scariot, V. (2019a). Drought stress adaptation modulates plant secondary metabolite production in Salvia dolomitica Codd. Industrial Crops and Products, 129, 85-96.

https://doi.org/10.1016/j.indcrop.2018.11.068

4. Caser, M., Demasi, S., Victorino, Í.M.M., Donno, D., Faccio, A., Lumini, E., Bianciotto, V., Scariot, V. (2019b). Arbuscular mycorrhizal fungi modulate the crop performance and metabolic profile of saffron in soilless cultivation. Agronomy, 9(5), 232.

https://doi.org/10.3390/agronomy9050232

5. Chen, G.L., Chen, S.G., Xiao, Y., Fu, N.L. (2018). Antioxidant capacities and total phenolic contents of 30 flowers. Industrial Crops and Products, 111, 430-445.

https://doi.org/10.1016/j.indcrop.2017.10.051

6. Covas, M.I., Fitó, M., Marrugat, J., Miró, E., Farré, M., De la Torre, R., Gimeno, E., López-Sabater, M.C., Lamuela-Raventós, R., De la Torre-Boronat, H.C. (2001). Coronary heart disease protective factors: Antioxidant effect of olive oil | Facteurs protecteurs de la maladie coronarienne: Effet antioxydant de l'huile d'olive. Therapie, 56(5), 607-611. Available at: [https://www. ncbi.nlm.nih.gov/pubmed/11806301]

7. de Morais, J.S., Sant'Ana, A.S., Dantas, A.M., Silva, B.S., Lima, M.S., Borges, G.C., Magnani, M. (2020). Antioxidant activity and bioaccessibility of phenolic compounds in white, red, blue, purple, yellow and orange edible flowers through a simulated intestinal barrier. Food Research International, 131, art. no. 109046.

https://doi.org/10.1016/j.foodres.2020.109046

8. Del Bo, C., Bernardi, S., Marino, M., Porrini, M., Tucci, M., Guglielmetti, S., Cherubini, A., Carrieri, B., Kirkup, B., Kroon, P., Zamora-Ros, R., Liberona, N.H., Andres-Lacueva, C., Riso, P.
(2019). Systematic review on polyphenol intake and health outcomes: is there sufficient evidence to define a health-promoting polyphenol-rich dietary pattern? Nutrients, 11 (6), art. no. 1355. https://doi.org/10.3390/nu11061355

9. Demasi, S., Caser, M., Donno, D., Ravetto Enri, S., Lonati, M., Scariot, V. (2021a). Exploring wild edible flowers as a source of bioactive compounds: New perspectives in horticulture. Folia Horticulturae, 33(1), 27-48.

https://doi.org/10.2478/fhort-2021-0004

10. Demasi, S., Caser, M., Lonati, M., Cioni, P. L., Pistelli, L., Najar, B., Scariot, V. (2018). Latitude and altitude influence secondary metabolite production in peripheral alpine populations of the mediterranean species Lavandula angustifolia Mill. Frontiers in Plant Science, 9, art. no. 983.

\section{https://doi.org/10.3389/fpls.2018.00983}

11. Demasi, S., Falla, N.M., Caser, M., Scariot, V. (2020). Postharvest aptitude of Begonia semperflorens and Viola cornuta edible flowers. Advances in Horticultural Science, 34(1S), 13-20. https://doi.org/10.13128/ahsc-7444

12. Demasi, S., Mellano, M.G., Falla, N.M., Caser, M., Scariot, V. (2021b). Sensory profile, shelf life, and dynamics of bioactive compounds during cold storage of 17 edible flowers. Horticulturae, 7(7), art. no. 166.

https://doi.org/10.3390/horticulturae7070166

13. Falla, N.M., Contu, S., Demasi, S., Caser, M., Scariot, V. (2020). Environmental impact of edible flower production: A case study. Agronomy, 10(4), 1-17.

https://doi.org/10.3390/agronomy10040579

14. Fernandes, L., Casal, S., Pereira, J.A., Saraiva, J.A., Ramalhosa, E. (2020). An overview on the market of edible flowers. Food Reviews International, 36(3), 258-275. https://doi.org/10.1080/87559129.2019.1639727

15. Fiehn, O. (2002). Metabolomics - the link between genotypes and phenotypes. In C. Town (Eds.), Functional Genomics, Springer, Dordrecht, The Netherlands, pp. 155-171. https://doi.org/10.1007/978-94-010-0448-0_11

16. Fraga, C.G., Croft, K.D., Kennedy, D.O., Tomás-Barberán, F.A. (2019). The effects of polyphenols and other bioactives on human health. Food \& Function, 10(2), 514-528. https://doi.org/10.1039/C8F001997E

17. Friedman, H., Agami, O., Vinokur, Y., Droby, S., Cohen, L., Refaeli, G., Resnick, N., Umiel, N. (2010). Characterization of yield, sensitivity to Botrytis cinerea and antioxidant content of several rose species suitable for edible flowers. Scientia Horticulturae, 123(3), 395-401.

https://doi.org/10.1016/j.scienta.2009.09.019

18. González-Barrio, R., Periago, M.J., Luna-Recio, C., Garcia-Alonso, F.J., Navarro-González, I. (2018). Chemical composition of the edible flowers, pansy (Viola wittrockiana) and snapdragon (Antirrhinum majus) as new sources of bioactive compounds. Food Chemistry, 252, 373-380.

https://doi.org/10.1016/j.foodchem.2018.01.102

19. Grassi, D., Necozione, S., Lippi, C., Croce, G., Valeri, L., Pasqualetti, P., Desideri, G., Blumberg, J.B., Ferri, C. (2005). Cocoa reduces blood pressure and insulin resistance and improves endothelium-dependent vasodilation in hypertensives. Hypertension, 46(2), 398-405.

https://doi.org/10.1161/01.HYP.0000174990.46027.70 
20. Grzeszczuk, M., Stefaniak, A., Pachlowska, A. (2016). Biological value of various edible flower species. Acta Scientiarum Polonorum Hortorum Cultus, 15(2), 109-119.

21. Guimarães, R., Barros, L., Carvalho, A.M., Ferreira, I.C.F.R (2010). Studies on chemical constituents and bioactivity of Rosa micrantha: An alternative antioxidants source for food, pharmaceutical, or cosmetic applications. Journal of Agricultural and Food Chemistry, 58(10), 6277-6284.

https://doi.org/10.1021/jf101394w

22. Guo, X., Tresserra-Rimbau, A., Estruch, R., Martínez-González, M.A., Medina-Remón, A., Castañer, O., Corella, D., Salas-Salvadó, J., Lamuela-Raventós, R.M. (2016). Effects of polyphenol, measured by a biomarker of total polyphenols in urine, on cardiovascular risk factors after a long-term follow-up in the PREDIMED study. Oxidative Medicine and Cellular Longevity, 2016, $1-11$.

https://doi.org/10.1155/2016/2572606

23. Hansawasdi, C., Kawabata, J., Kasai, T. (2001). Hibiscus acid as an inhibitor of starch digestion in the Caco-2 cell model system. Bioscience, Biotechnology and Biochemistry, 65(9), 2087-2089. https://doi.org/10.1271/bbb.65.2087

24. Hou, D.X., Tong, X., Terahara, N., Luo, D., Fujii, M. (2005). Delphinidin 3-sambubioside, a Hibiscus anthocyanin, induces apoptosis in human leukemia cells through reactive oxygen species-mediated mitochondrial pathway. Archives of Biochemistry and Biophysics, 440(1), 101-109. https://doi.org/10.1016/j.abb.2005.06.002

25. Julious, S.A. (2005). Sample size of 12 per group rule of thumb for a pilot study. Pharmaceutical Statistics, 4(4), 287-291. https://doi.org/10.1002/pst.185

26. Kim, J.K., So, H., Youn, M.J., Kim, H.J., Kim, Y., Park, C., Kim, S.J., Ha, Y.A., Chai, K.Y., Kim, S.M., Kim, K.Y., Park, R. (2007). Hibiscus sabdariffa L. water extract inhibits the adipocyte differentiation through the PI3-K and MAPK pathway. Journal of Ethnopharmacology, 114(2), 260-267.

https://doi.org/10.1016/j.jep.2007.08.028

27. Kong, C.S., Lee, J.I., Kim, J.A., Seo, Y. (2011). In vitro evaluation on the antiobesity effect of lignans from the flower buds of Magnolia denudata. Journal of Agricultural and Food Chemistry, 59(10), 5665-5670.

https://doi.org/10.1021/jf200230s

28. Kumar, N., Bhandari, P., Singh, B., Bari, S.S. (2009). Antioxidant activity and ultra-performance LC-electrospray ionization-quadrupole time-of-flight mass spectrometry for phenolics-based fingerprinting of rose species: Rosa damascena, Rosa bourboniana and Rosa brunonii. Food and Chemical Toxicology, 47(2), 361-367.

https://doi.org/10.1016/j.fct.2008.11.036

29. Kuntz, S., Rudloff, S., Asseburg, H., Borsch, C., Fröhling, B., Unger, F., Dold, S., Spengler, B., Römpp, A., Kunz, C. (2015). Uptake and bioavailability of anthocyanins and phenolic acids from grape/blueberry juice and smoothie in vitro and in vivo. British Journal of Nutrition, 113(7), 1044-1055. https://doi.org/10.1017/S0007114515000161

30. Lattanzio, F., Greco, E., Carretta, D., Cervellati, R., Govoni, P., Speroni, E. (2011). In vivo anti-inflammatory effect of Rosa canina L. extract. Journal of Ethnopharmacology, 137(1), 880-885. https://doi.org/10.1016/j.jep.2011.07.006
31. Lee, E.J., Kim, J.S., Kim, H.P., Lee, J.H., Kang, S.S. (2010). Phenolic constituents from the flower buds of Lonicera japonica and their 5-lipoxygenase inhibitory activities. Food Chemistry, 120(1), 134-139.

https://doi.org/10.1016/j.foodchem.2009.09.088

32. Li, A.N., Li, S., Li, H.B., Xu, D.P., Xu, X.R., Chen, F. (2014). Total phenolic contents and antioxidant capacities of 51 edible and wild flowers. Journal of Functional Foods, 6(1), 319-330. https://doi.org/10.1016/j.jff.2013.10.022

33. Lim, T.K. (2014a). Edible Medicinal And Non-Medicinal Plants. Volume 7, Flowers. Springer, Dordrecht, The Netherlands. https://doi.org/10.1007/978-94-007-7395-0

34. Lim, T. K. (2014b). Edible Medicinal and Non-Medicinal Plants. Volume 8, Flowers. Springer, Dordrecht, The Netherlands. https://doi.org/10.1007/978-94-017-8748-2

35. Lin, H.H., Huang, H.P., Huang, C.C., Chen, J.H., Wang, C.J. (2005). Hibiscus polyphenol-rich extract induces apoptosis in human gastric carcinoma cells via p53 phosphorylation and p38 MAPK/FasL cascade pathway. Molecular Carcinogenesis, 43(2), 86-99. https://doi.org/10.1002/mc.20103

36. Liu, J., He, Z., Ma, N., Chen, Z.Y. (2020a). Beneficial effects of dietary polyphenols on high-fat diet-induced obesity linking with modulation of gut microbiota. Journal of Agricultural and Food Chemistry, 68(1), 33-47.

https://doi.org/10.1021/acs.jafc.9b06817

37. Liu, R.H. (2003). Health benefits of fruit and vegetables are from additive and synergistic combinaions of phytochemicals. The American Journal of Clinical Nutrition, 78(3), 517S-520S. https://doi.org/10.1093/ajcn/78.3.517s

38. Lo, C.W., Huang, H.P., Lin, H.M., Chien, C.T., Wang, C.J. (2007). Effect of Hibiscus anthocyanins-rich extract induces apoptosis of proliferating smooth muscle cell via activation of P38 MAPK and 553 pathway. Molecular Nutrition \& Food Research, 5l(12), 1452-1460.

https://doi.org/10.1002/mnfr.200700151

39. Loizzo, M.R., Pugliese, A., Bonesi, M., Tenuta, M.C., Menichini, F., Xiao, J., Tundis, R. (2016). Edible flowers: a rich source of phytochemicals with antioxidant and hypoglycemic properties. Journal of Agricultural and Food Chemistry, 64(12), 2467-2474. https://doi.org/10.1021/acs.jafc.5b03092

40. Lu, B., Li, M., Yin, R. (2016). Phytochemical content, health benefits, and toxicology of common edible flowers: a review (2000-2015). Critical Reviews in Food Science and Nutrition, 56, S130-S148.

https://doi.org/10.1080/10408398.2015.1078276

41. Manach, C., Mazur, A., Scalbert, A. (2005). Polyphenols and prevention of cardiovascular diseases. Current Opinion in Lipidology, 16(1), 77-84.

https://doi.org/10.1097/00041433-200502000-00013

42. Martínez, M.C., Santiago, J.L., Boso, S., Gago, P., Álvarez-Acero, I., De Vega, M.E., Martínez-Bartolomé, M., Álvarez-Nogal, R., Molíst, P., Caser, M., Scariot, V., Gómez-García, D. (2020). Narcea - an unknown, ancient cultivated rose variety from northern Spain. Horticulture Research, 7(1), art. no. 44.

https://doi.org/10.1038/s41438-020-0266-8

43. Medina-Remón, A., Barrionuevo-González, A., Zamora-Ros, R., Andres-Lacueva, C., Estruch, R., Martínez-González, M.-Á., Diez-Espino, J., Lamuela-Raventos, R.M. (2009). Rapid Fo- 
lin-Ciocalteu method using microtiter 96-well plate cartridges for solid phase extraction to assess urinary total phenolic compounds, as a biomarker of total polyphenols intake. Analytica Chimica Acta, 634(1), 54-60.

https://doi.org/10.1016/j.aca.2008.12.012

44. Medina-Remón, A., Casas, R., Tressserra-Rimbau, A., Ros, E., Martínez-González, M. A., Fitó, M., Corella, D., Salas-Salvadó, J., Lamuela-Raventos, R.M., Estruch, R. (2017). Polyphenol intake from a Mediterranean diet decreases inflammatory biomarkers related to atherosclerosis: a substudy of the PREDIMED trial. British Journal of Clinical Pharmacology, 83(1), 114-128. https://doi.org/10.1111/bcp.12986

45. Mennen, L.I., Sapinho, D., Ito, H., Bertrais, S., Galan, P., Hercberg, S., Scalbert, A. (2006). Urinary flavonoids and phenolic acids as biomarkers of intake for polyphenol-rich foods. British Journal of Nutrition, 96(1), art. no. 191. https://doi.org/10.1079/BJN20061808

46. Mohsen, E., Younis, I.Y., Farag, M.A. (2020). Metabolites profiling of Egyptian Rosa damascena Mill. flowers as analyzed via ultra-high-performance liquid chromatography-mass spectrometry and solid-phase microextraction gas chromatography-mass spectrometry in relation to its anti-collagenase skin effect. Industrial Crops and Products, 155, art. no. 112818.

https://doi.org/10.1016/j.indcrop.2020.112818

47. Najar, B., Demasi, S., Caser, M., Gaino, W., Cioni, P.L., Pistelli, L., Scariot, V. (2019). Cultivation substrate composition influences morphology, volatilome and essential oil of Lavandula angustifolia Mill. Agronomy, 9(8), art. no. 411.

https://doi.org/10.3390/agronomy9080411

48. Navarro-González, I., González-Barrio, R., García-Valverde, V., Bautista-Ortín, A.B., Periago, M.J. (2015). Nutritional composition and antioxidant capacity in edible flowers: Characterisation of phenolic compounds by HPLC-DAD-ESI/MSn. International Journal of Molecular Sciences, 16(1), 805-822.

https://doi.org/10.3390/ijms16010805

49. Neveu, V., Perez-Jiménez, J., Vos, F., Crespy, V., du Chaffaut, L., Mennen, L., Knox, C., Eisner, R., Cruz, J., Wishart, D., Scalbert, A. (2010). Phenol-Explorer: an online comprehensive database on polyphenol contents in foods. Database, 2010, bap024-bap024. https://doi.org/10.1093/database/bap024

50. Nielsen, S.E., Freese, R., Kleemola, P., Mutanen, M. (2002). Flavonoids in human urine as biomarkers for intake of fruits and vegetables. Cancer Epidemiology Biomarkers and Prevention, 11(5), 459-466. Available at: [https://www.ncbi.nlm.nih.gov/ pubmed/12010860]

51. Oboh, G., Ademosun, A.O., Ayeni, P.O., Omojokun, O.S., Bello, F. (2015). Comparative effect of quercetin and rutin on $\alpha$-amylase, $\alpha$-glucosidase, and some pro-oxidant-induced lipid peroxidation in rat pancreas. Comparative Clinical Pathology, 24(5), 1103-1110.

https://doi.org/10.1007/s00580-014-2040-5

52. Ozdal, T., Sela, D.A., Xiao, J., Boyacioglu, D., Chen, F., Capanoglu, E. (2016). The reciprocal interactions between polyphenols and gut microbiota and effects on bioaccessibility. Nutrients, $8(2)$, art. no. 78 .

https://doi.org/10.3390/nu8020078

53. Pal, P.K., Singh, R.D. (2013). Understanding crop-ecology and agronomy of Rosa damascena Mill. for higher productivity. Australian Journal of Crop Science, 7(2), 196-205.
54. Pérez-Jiménez, J., Hubert, J., Hooper, L., Cassidy, A., Manach, C., Williamson, G., Scalbert, A. (2010a). Urinary metabolites as biomarkers of polyphenol intake in humans: a systematic review. The American Journal of Clinical Nutrition, 92(4), 801-809. https://doi.org/10.3945/ajcn.2010.29924

55. Pérez-Jiménez, J., Neveu, V., Vos, F., Scalbert, A. (2010b). Identification of the 100 richest dietary sources of polyphenols: an application of the Phenol-Explorer database. European Journal of Clinical Nutrition, 64(S3), S112-S120.

https://doi.org/10.1038/ejcn.2010.221

56. Piccolella, S., Crescente, G., Pacifico, F., Pacifico, S. (2018). Wild aromatic plants bioactivity: a function of their (poly)phenol seasonality? A case study from Mediterranean area. Phytochemistry Reviews, 17(4), 785-799.

https://doi.org/10.1007/s11101-018-9558-0

57. Pires, T.C.S.P., Barros, L., Santos-Buelga, C., Ferreira, I.C.F.R. (2019). Edible flowers: Emerging components in the diet. Trends in Food Science \& Technology, 93, 244-258. https://doi.org/10.1016/j.tifs.2019.09.020

58. Preuss, H.G., Echard, B., Bagchi, D., Stohs, S. (2007). Inhibition by natural dietary substances of gastrointestinal absorption of starch and sucrose in rats and pigs: 1. Acute studies. International Journal of Medical Sciences, 4(4), 196-202.

https://doi.org/10.7150/ijms.4.196

59. Rop, O., Mlcek, J., Jurikova, T., Neugebauerova, J., Vabkova, J. (2012). Edible flowers - A new promising source of mineral elements in human nutrition. Molecules, 17(6), 6672-6683. https://doi.org/10.3390/molecules17066672

60. Rothwell, J.A., Perez-Jimenez, J., Neveu, V., Medina-Remon, A., M'Hiri, N., Garcia-Lobato, P., Manach, C., Knox, C., Eisner, R., Wishart, D.S., Scalbert, A. (2013). Phenol-Explorer 3.0: a major update of the Phenol-Explorer database to incorporate data on the effects of food processing on polyphenol content. Database, 2013, art. no. bat070.

https://doi.org/10.1093/database/bat070

61. Roura, E., Andrés-Lacueva, C., Estruch, R., Lamuela-Raventós, R.M. (2006). Total polyphenol intake estimated by a modified folin-ciocalteu assay of urine. Clinical Chemistry, 52(4), 749-752. https://doi.org/10.1373/clinchem.2005.063628

62. Santos-Buelga, C., Gonzalez-Manzano, S., Dueñas, M., Gonzalez-Paramas, A.M. (2012). Extraction and isolation of phenolic compounds. Methods in Molecular Biology, 864, 427-464. https://doi.org/10.1007/978-1-61779-624-1_17

63. Scariot, V., Gaino, W., Demasi, S., Caser, M., Ruffoni, B. (2018). Flowers for edible gardens: combinations of species and colours for northwestern Italy. Acta Horticulturae, 1215, 363-368. https://doi.org/10.17660/ActaHortic.2018.1215.67

64. Shader, R.I. (2015). Proof of feasibility: what a pilot study is and is not. Clinical Therapeutics, 37(7), 1379-1380. https://doi.org/10.1016/j.clinthera.2015.06.011

65. Slinkard, K., Singleton, V.L. (1977). Total phenol analysis: automation and comparison with manual methods. American Journal of Enology and Viticulture, 28(1), 49-55

66. Smulders, M.J.M., Arens, P., Bourke, P.M., Debener, T., Linde, M., De Riek, J., Leus, L., Ruttink, T., Baudino, S., Hibrant Saint-Oyant, L., Clotault, J., Foucher, F. (2019). In the name of the rose: a roadmap for rose research in the genome era. Horticulture Research, 6(1), art. no. 65. https://doi.org/10.1038/s41438-019-0156-0 
67. Spencer, J.P.E., Abd El Mohsen, M.M., Minihane, A.M., Mathers, J.C. (2008). Biomarkers of the intake of dietary polyphenols: strengths, limitations and application in nutrition research. British Journal of Nutrition, 99(1), 12-22. https://doi.org/10.1017/S0007114507798938

68. Takahashi, J.A., Rezende, F.A.G.G., Moura, M.A.F., Dominguete, L.C.B., Sande, D. (2020). Edible flowers: Bioactive profile and its potential to be used in food development. Food Research International, 129, art. no. 108868 .

https://doi.org/10.1016/j.foodres.2019.108868

69. Teng, H., Chen, L. (2019). Polyphenols and bioavailability: an update. Critical Reviews in Food Science and Nutrition, 59(13), 2040-2051.

https://doi.org/10.1080/10408398.2018.1437023

70. Tomas-Barberan, F., García-Villalba, R., Quartieri, A., Raimondi, S., Amaretti, A., Leonardi, A., Rossi, M. (2014). In vitro transformation of chlorogenic acid by human gut microbiota. Molecular Nutrition \& Food Research, 58(5), 1122-1131.

https://doi.org/10.1002/mnfr.201300441

71. Tresserra-Rimbau, A., Rimm, E.B., Medina-Remón, A., Martínez-González, M.A., de la Torre, R., Corella, D., Salas-Salvadó, J., Gómez-Gracia, E., Lapetra, J., Arós, F., Fiol, M., Ros, E., Serra-Majem, L., Pintó, X., Saez, G.T., Basora, J., Sorlí, J.V., Martínez, J.A., Vinyoles, E., Ruiz-Gutiérrez, V., Estruch, R., Lamuela-Raventós, R.M. (2014a). Inverse association between habitual polyphenol intake and incidence of cardiovascular events in the PREDIMED study. Nutrition, Metabolism and Cardiovascular Diseases, 24(6), 639-647.

https://doi.org/10.1016/j.numecd.2013.12.014

72. Tresserra-Rimbau, A., Rimm, E.B., Medina-Remón, A., Martínez-González, M.A., López-Sabater, M.C., Covas, M.I., Corella, D., Salas-Salvadó, J., Gómez-Gracia, E., Lapetra, J., Arós, F., Fiol, M., Ros, E., Serra-Majem, L., Pintó, X., Muñoz, M.A., Gea, A., Ruiz-Gutiérrez, V., Estruch, R., Lamuela-Raventós, R.M. (2014b).
Polyphenol intake and mortality risk: a re-analysis of the PREDIMED trial. BMC Medicine, 12(1), art. no. 77.

https://doi.org/10.1186/1741-7015-12-77

73. Velusami, C.C., Agarwal, A., Mookambeswaran, V. (2013). Effect of Nelumbo nucifera petal extracts on lipase, adipogenesis, adipolysis, and central receptors of obesity. Evidence-Based Complementary and Alternative Medicine, 2013, art. no. 145925.

https://doi.org/10.1155/2013/145925

74. Wedick, N.M., Pan, A., Cassidy, A., Rimm, E.B., Sampson, L., Rosner, B., Willett, W., Hu, F.B., Sun, Q., van Dam, R.M. (2012). Dietary flavonoid intakes and risk of type 2 diabetes in US men and women. The American Journal of Clinical Nutrition, 95(4), 925-933. https://doi.org/10.3945/ajcn.111.028894

75. Zamora-Ros, R., Rabassa, M., Cherubini, A., Urpí-Sardà, M., Bandinelli, S., Ferrucci, L., Andres-Lacueva, C. (2013). High concentrations of a urinary biomarker of polyphenol intake are associated with decreased mortality in older adults. The Journal of Nutrition, 143(9), 1445-1450.

https://doi.org/10.3945/jn.113.177121

76. Zamora-Ros, R., Rabassa, M., Cherubini, A., Urpi-Sarda, M., Llorach, R., Bandinelli, S., Ferrucci, L., Andres-Lacueva, C. (2011). Comparison of 24-h volume and creatinine-corrected total urinary polyphenol as a biomarker of total dietary polyphenols in the Invecchiare InCHIANTI study. Analytica Chimica Acta, 704(1-2), 110-115.

https://doi.org/10.1016/j.aca.2011.07.035

77. Zhang, J., Rui, X., Wang, L., Guan, Y., Sun, X., Dong, M. (2014). Polyphenolic extract from Rosa rugosa tea inhibits bacterial quorum sensing and biofilm formation. Food Control, 42, 125-131. https://doi.org/10.1016/j.foodcont.2014.02.001

78. Zheng, J., Yu, X., Maninder, M., Xu, B. (2018). Total phenolics and antioxidants profiles of commonly consumed edible flowers in China. International Journal of Food Properties, 21 (1), 1524-1540. https://doi.org/10.1080/10942912.2018.1494195 